\title{
Cashew (Anacardium occidentale L.) Production, Processing Facilities and Quality Assessment in Kafubulum Chiefdom, Sierra Leone
}

\author{
Turay, F.; Lahai, P. M.; Luseni, M. M.; Carpenter, P. A.; Bayon, M. S.; and \\ Kallon, V. F.
}

Kenema Forestry and Tree Crops Research Centre (KFTCR) of Sierra Leone Agricultural Research Institute (SLARI), Sierra Leone *Corresponding Author: fodayturay83@yahoo.com

\begin{abstract}
The research was conducted to investigate the cashew production, processing facilities and quality assessment in Sierra Leone Agricultural Research Institute (SLARI)/Kenema Forestry and Tree Crops Research Centre (KFTCRC), Sierra Leone. A total of 80structured questionnaires on cashew production, processing facilities and quality assessment were administered to farmers including men and women in the Kafubulum Chiefdom, Port Loko District. Data obtained were analysed descriptively and quantitatively. Simple arithmetic like percentages were used to analyze the data. Tables were then used to present the facts and finding recording the research. The research revealed the Red and Yellow cashew colours were the varieties cultivated in the study area and red cashew gave better yield in the Kafubulum Chiefdom from the interview conducted. Upon the two colours, Red reported to be high yielding with 55\% respondents. Also, cashew farmers have no processing facility except for roasting and drying the cashew kernel 100\% each from the results obtained. This was shown from the analyses that $100 \%$ of these producers were willing to process their cashew to kernel.In general, the quality of the cashew kernels were high as farmers were able to maintain the exact required kernel 8\% moisture content through colour observation and taste and Premium with 52.5\% kernel grades were discovered.
\end{abstract}

Keywords-Cashew, nut, production, processing, quality.

\section{INTRODUCTION}

\subsection{Background to the study}

Cashew (Anacardiumoccidentale L.) is one of the important commercial plantation crops, which today is deemed to be the source of dollar earning crop for the country. It is in fact, a poor man's crop and the rich man's favorite snack food all over the world. The cashew is a kidney shaped drupaceous nut, greenish gray in colour. A single nut is 3 to $5 \mathrm{~cm}$ in length and 2 to $3.5 \mathrm{~cm}$ in width measures about 3 to $20 \mathrm{~g}$ weight.The cultivated cashew is a low spreading ever green tree of the tropics. It is presumed that cashew was originally introduced into India mainly for checking soil erosion. But gradually it gained commercial importance and is one of the ten top foreign exchange earners. In the earlier years of cashew production in India, the apple was considered valuable onto the 107th century when the cashew kernel gained commercial importance, and hence found favour among consumers. Prior to the First World War quantities of cashew kernel was exported from India to USA.

The French, Portuguese and Dutch seafarers described cashew from Brazil in the sixteenth century and the first illustrative description of cashew was given by a French naturalist in 1558 A.D. Cashew was introduced to the Malabar Coast of India in the sixteenth century by the Spaniards, and probably served as a locus of dispersal to other centers in India and South East Asia. The Spaniard who have been aware of the use of cashew in medicine, foods and beverages, probably visualized the potential importance of this crop to India. "Acaju" is the name given to cashew by 
the native Tapi Indians of Brazil and the French name "Acajou" is the nearest equivalence of the original name.

The Portuguese dropped the letter ' $A$ ' and became 'Caju' in Portuguese. The Kashmiri, Panjabi, Hindi, Marathi and Gujarati lexicons in India also referred to the cashew as 'Caju'. It is probable that the use of kernel spread from Goa to Maharashtra, then to Gujarat, Rajasthan, Punjab and Kashmir and other Hindi speaking areas. In Kerala, it is called "Parangi Andi" meaning foreign or "Portuguese nut". It is also known as "Kasu Andi", "Kasu" meaning money and "Andi" the nut. In Tamil, it is known as "Mundiri" indicating the position and shape of the nut. In Oriya it is known as "Lanka Beeja" indicating that cashew reached Orissa by sea from Sri Lanka.

The Bengalis know cashew as "Hijlibadam" and Assamese refer to the nut as "CajuBadam". Thus, most of the names used in India were derived from the Portuguese name "Caju" for cashew.

This serves as a piece of evidence that the cashew originated in Brazil (Nambiar, 1979). When the price of the nuts became attractive, it wasnot uncommon to see some cashew growers harvesting immature nuts the apple of which has not even started developing. In the absence of a market for cashew apple, farmers do harvest nuts early causing loss to themselves as well as to the processors.

Some intelligent farmers harvest nuts from the fully ripened cashew apple or ripe fallen cashew apples, so these matured nuts give good quality bold kernels on processing and it is profitable to both farmers and processors (Vaidehi, 2000).

At present, the major cashew growing countries of the world are India, Brazil, Indonesia, Vietnam, Nigeria, Mozambique and Tanzania.

The productivity of cashew nut at national level is $593 \mathrm{~kg}$ per ha which is quite less than the potentiality of more than 1000 $\mathrm{kg}$ per ha if the correct planting materials and latest technologies could be adopted (Directorate of Cashew Development, Cochin, 2008).

\subsection{Statement of the Problem}

Cashew nut production and processing is another source of employment and income generation especially to the rural people in Port Loko, Bombali and Kambia Districts. It makes poor rural farmers realize foreign exchange earnings. So, its role is important in the determination of economic development of the districts. Similarly, in Kambia and the other Districts, it plays a key role in employment generation and economic empowerment. The economic importance of the cashew nut production and processing is based on the great number of workers employed and the amount of foreign currency earned through cashew nut exports.

The majority of all cashew processors are women i.e. about $95 \%$. This is also true in the case of cashew processors in Kambia, Port Loko and Bombali Districts. Except in roasting but, women workers are engaged in shelling, peeling, grading, and packaging sections.

The problem of the present research is to analyze the cashew nut production and processing facilities in the aforementioned district in Sierra Leone.

The most employed types of cashew nut processing stages are drying, roasting, shelling, peeling, rehumidification, grading, packaging and fabrication of processing equipment. Moreover, time engaged in cashew processing is from 8:30 AM to 5:30 PM. Hence, through this research earnest attempt will be made by the researcher to find out the factors that determine the status of cashew production and processing facilities in the Port Loko District.

\subsection{General and Specific Objectives of the Research}

\subsubsection{General Objective of the Research}

The main aim of this research wasto investigate cashew (Anacardiumoccidentale L) Production, Processing Facilities and Quality Assessment in Sierra Leone.

\subsubsection{Specific Objectives of the Research}

In order to achieve the study goal, the following specific objectives were taken into cognizance as thus below:

$>$ determined the availability of cashew processing equipment and fabrication units.

$>$ assessed the quality of cashew nut produced in the chiefdom.

$>$ identified the constraints associated with production, processing and marketing of cashew nut.

\subsection{Justification of the Research}

Although several efforts have been made in different parts of the world to improve on the cashew nut production and processing but, serious attention has not been given to fabrication units. This research unearthed some of the problems faced in the processing of Cashew Nut and the Cashew Apple in the study area. The current research will serve as the point of entry for the introduction of appropriate processing technology to upgrading cashew nut products to 
premium. It will also serve as a baseline for future work on post-harvest technology of cashew nut production and processing facilities in Sierra Leone.

\subsection{Limitations of the Research}

This research was limited on the following factors:

- Availability of secondary data was a big issue as people have not really have written on this topic.

- Financial constraint in getting stationaries and even getting to website was not easy.

- Transportation: It was difficult to move from Kenema to Port Loko District for data acquisition.

\section{MATERIALS AND METHODS}

\subsection{Study Area}

This research was conducted in the Kafubulum Chiefdom, Port Loko District, North of Sierra Leone.

\subsection{Data Collection}

\subsubsection{Sample Size}

80 Cashew Farmers including men and women were administered structured questionnaires on cashew production and processing facilities.

\subsubsection{Instrumentation}

This includes:

\subsubsection{Questionnaire}

A well-structured questionnaire was tailored according to the directives of this research. The questionnaires were distributed among respondents in order to solicit their responses.

\subsection{Data Analysis}

Data were analysed descriptively and quantitatively. Simple arithmetic like percentages were used to analyze the data. Tables were then used to present the facts and finding and recording of the research.

\section{CHARACTERISTICS}

\subsection{Demographic Characteristics}

Table 3.1: Demographic characteristics of cashew farmers

\begin{tabular}{|c|c|c|}
\hline Variable & $\begin{array}{l}\text { Frequency } \\
(\mathrm{n}=80)\end{array}$ & Percentage \\
\hline \multicolumn{3}{|c|}{ Sex } \\
\hline Male & 80 & 100 \\
\hline Female & 0 & 0 \\
\hline Total & 100 & 100 \\
\hline \multicolumn{3}{|c|}{ Age Bracket (Yrs) } \\
\hline $15-25$ & 0 & 0 \\
\hline $26-35$ & 48 & 60 \\
\hline $36-45$ & 32 & 40 \\
\hline $46+$ & 0 & 0 \\
\hline Total & 80 & 100 \\
\hline \multicolumn{3}{|c|}{ Experience in Cashew farming (Yrs) } \\
\hline $0-2$ & 40 & 50 \\
\hline $3-5$ & 0 & 0 \\
\hline $6-8$ & 40 & 50 \\
\hline $9+$ & 0 & 0 \\
\hline Total & 80 & 100 \\
\hline
\end{tabular}

Table 3.1 above shows that male cashew farmers were highly engaged in cashew production with $100 \%$ respondents. It was observed that there was no gender balance in cashew production from the interview conducted. Accordingly, $60 \%$ (48) of cashew farmers interviewed were within the age brackets of 26-35 years while $40 \%$ (32) of them were within $36-45$ years old. It can also be depicted that young people within the ages of 15-25 years do not involve in cashew processing likewise the age of 46 years and above. Half $(50 \%)$ the total respondents have spent two or less years in cashew production and in the same vain $50 \%$ of them have six to eight years of experience in producing cashew in that part of the country. 


\subsection{Cashew Production}

Table 3.2: Shows the estimated size of the cashew farm

\begin{tabular}{|c|c|c|}
\hline $\begin{array}{c}\text { Size } \\
\text { (Acre) }\end{array}$ & No. of respondent & Percentage (\%) \\
\hline $1-5$ & 30 & 37.5 \\
\hline $6-10$ & 50 & 62.5 \\
\hline Total & 80 & 100 \\
\hline
\end{tabular}

According to table 3.2 above, $37.5 \%$ of the cashew farms were within $1-5$ acres while $62.5 \%$ reported on the farm size ranging from 6-10 acres. It can be depicted form the data analysis that cashew farmers in the study area did not grow cashew in large scale, it could be access to land availability or lack of capital to invest in cashew production and processing.

Table 3.3: Shows the varieties of cashew grown

\begin{tabular}{|c|c|c|}
\hline Variety & No. of respondent & Percentage (\%) \\
\hline Red & 44 & 55 \\
\hline Oblong & 0 & 0 \\
\hline Yellow & 36 & 45 \\
\hline Pyriform & 0 & 0 \\
\hline Variegated & 0 & 0 \\
\hline Tall & 0 & 0 \\
\hline Round & 0 & 0 \\
\hline Dwarf & 0 & 0 \\
\hline Other & 0 & 0 \\
\hline Total & 80 & 100 \\
\hline
\end{tabular}

On the table 3.3, 55\% of the Red Colour cashew variety was produced in the Port Loko District in Northernof Sierra Leone and $45 \%$ was Yellow variety. It shows that only two varieties of cashew were produced in the district. This was so because of the availability of cashew varieties in Sierra Leone. Like in Ghana there are numerous cashew varieties available such as SG 266, SG 276, SG 185, SG 278, SG 273, BE 079, BE 107, SG 261, TAN 393 and SG 265 and many more. However, these cashew varieties are available and recently established in the Kpuwabu and Pendembu Research Stations of Kenema Forestry and Tree Crops Research Centre (KFTCRC) of the Sierra Leone Agricultural Research Institute (SLARI).
Table 3.4: Shows the time of cashew harvesting

\begin{tabular}{|c|c|c|}
\hline Time (moth) & $\begin{array}{c}\text { No. of } \\
\text { respondent }\end{array}$ & Percentage (\%) \\
\hline January-March & 0 & 0 \\
\hline April-June & 80 & 100 \\
\hline July-September & 0 & 0 \\
\hline $\begin{array}{c}\text { October- } \\
\text { December }\end{array}$ & 0 & 0 \\
\hline Throughout & 0 & 0 \\
\hline Total & 80 & 100 \\
\hline
\end{tabular}

Table 3.4 above shows the harvesting time of cashew which was between April-June and indicated 100\% response from the interview conducted. However, harvesting of cashew may vary based on the variety and climatic condition. It was reported that a community called Gbogoma Junction in the Kenema District, cashew tree bears two times every year. Also, a cashew tree at the Ministry of Agriculture and Forestry (MAF)'s Compound in IDA Kenema, bears two times a year and is a Red Colour Cashew.

Table 3.5: Shows methods used in cashew harvesting

\begin{tabular}{|c|c|c|}
\hline Method & No. of respondent & Percentage (\%) \\
\hline Hand picking & 32 & 40 \\
\hline Knife & 0 & 0 \\
\hline Fall & 48 & 60 \\
\hline Total & 80 & 100 \\
\hline
\end{tabular}

The analysis above revealed that $60 \%$ of the farmers did not harvest their cashew; instead they wait until when the cashew nut and its apple fall on the ground. However, $40 \%$ violated the rule of ripe cashew by the method of hand picking which is not recommended. The principle of wait until when the ripe cashew apple falls has not been implemented yet all over in the study area as demonstrated with the result above. Except for juice production, ripe cashew apple has to be harvested by hands. 


\subsection{Cashew Processing}

Table 3.6: Shows the respondents who processed and those that do not process cashew

\begin{tabular}{|c|c|c|}
\hline Option & No. of respondent & Percentage (\%) \\
\hline Yes & 80 & 100 \\
\hline No & 0 & 0 \\
\hline Total & 80 & 100 \\
\hline
\end{tabular}

From table 3.6 above, it came out clearly that all cashew producers with $100 \%$ normally process their cashew before sales. The results also showed that cashew is a crop that is processed before packaging and marketing.

Table 3.7: Shows stages of cashew processing done by farmers

\begin{tabular}{|c|c|c|}
\hline Stage & $\begin{array}{c}\text { No. of } \\
\text { respondent }\end{array}$ & Percentage (\%) \\
\hline Roasting & 54 & 67.5 \\
\hline Drying & 26 & 32.5 \\
\hline $\begin{array}{c}\text { Collection of } \\
\text { kernels }\end{array}$ & 0 & 0 \\
\hline Total & 80 & 100 \\
\hline
\end{tabular}

The analysis above revealed that $67.5 \%$ of cashew farmers roasted their cashew nut, but however, $32.5 \%$ donot roast the nut before drying. It also showed that not all cashew processing stages were done in the processing of cashew nut with $0 \%$ respondent for the remaining processing stages.

Table 3.8: Shows the methods used in cashew separation by farmers

\begin{tabular}{|c|c|c|}
\hline Method & $\begin{array}{l}\text { No. of } \\
\text { respondent }\end{array}$ & Percentage (\%) \\
\hline Cutlass & 0 & 0 \\
\hline Stick & 0 & 0 \\
\hline Knife & 24 & 30 \\
\hline By hand & 56 & 70 \\
\hline other & 0 & 0 \\
\hline Total & 80 & 100 \\
\hline
\end{tabular}

According to table 3.8, the respondents agreed that they normally separated their Cashew Apple from the Cashew Nut with rope with $70 \%$ value and the remaining 30\% use their hands for separating the Nut from the Apple. This was so because cashew farmers were trained how to separate the ripe cashew apple from the nut. No other method (s) were discovered from the cashew farmers for the aforementioned cashew processing stage.

Table 3.9: Shows the problems faced in cashew separation

\begin{tabular}{|c|c|c|}
\hline Problem & $\begin{array}{c}\text { No. of } \\
\text { respondent }\end{array}$ & Percentage (\%) \\
\hline Kernel damage & 0 & 0 \\
\hline Apple damage & 80 & 100 \\
\hline CNSL damage & 0 & 0 \\
\hline Total & 80 & 100 \\
\hline
\end{tabular}

Apple damage was a major problem faced by cashew farmers during separation as reported intable 3.9 with $100 \%$ agreed by the respondents interviewed. However, cashew farmers needed more training on the separation of ripe cashew apple from the nut to avoid the $100 \%$ damage. However, Kernel damage and Cashew Nut Shell Liquid (CNSL) were not experienced as problems faced in cashew separation as $0 \%$ reported for both cases.

Table 3.10: Shows the respondents normally dry cashew nut

\begin{tabular}{|c|c|c|}
\hline Option & $\begin{array}{c}\text { No. of } \\
\text { respondent }\end{array}$ & Percentage (\%) \\
\hline Yes & 80 & 100 \\
\hline No & 0 & 0 \\
\hline Total & 80 & 100 \\
\hline
\end{tabular}

The option yes was chosen by the respondents that in deed the cashew farmers were not only producing cashew but also processed the nuts as value addition of cashew production, processing and marketing systems.

Table 3.11: Shows where the respondents dry their cashew nut

\begin{tabular}{|c|c|c|}
\hline Place & $\begin{array}{c}\text { No. of } \\
\text { respondent }\end{array}$ & Percentage (\%) \\
\hline Drying floor & 80 & 100 \\
\hline Raised platform & 0 & 0 \\
\hline
\end{tabular}




\begin{tabular}{|c|c|c|}
\hline Solar dryer & 0 & 0 \\
\hline Wood dryer & 0 & 0 \\
\hline Total & 80 & 100 \\
\hline
\end{tabular}

Drying floor was the only place where cashew producers dried their produce with $100 \%$ agreed while other drying methods were not practiced. For quality cashew product, it is not recommended to dry cashew nuts on drying floor rather under shade for better quality and avoid foreign particles.

Table 3.12: Shows the duration of cashew nuts drying

\begin{tabular}{|c|c|c|}
\hline Duration (day) & $\begin{array}{c}\text { No. of } \\
\text { respondent }\end{array}$ & Percentage (\%) \\
\hline 1 & 0 & 0 \\
\hline 2 & 0 & 0 \\
\hline 3 & 22 & 0 \\
\hline 4 & 0 & 0 \\
\hline 5 & 0 & 72.5 \\
\hline 1 week & 58 & 100 \\
\hline Total & 80 & 27.5 \\
\hline
\end{tabular}

From table 3.12 above, most cashew farmers dry their cashew nuts for a period of 1 week with $72.5 \%$ during the interview conducted in Port Loko District. Also, few cashew farmers dry their cashew nuts within a period of 3 days before sold to their contact partners or buying agents.

Table 3.13: Shows problems faced duration cashew nuts drying

\begin{tabular}{|c|c|c|}
\hline Problem & $\begin{array}{c}\text { No. of } \\
\text { respondent }\end{array}$ & Percentage (\%) \\
\hline Swelling & 20 & 25 \\
\hline Theft & 60 & 75 \\
\hline Burnt & 0 & 0 \\
\hline Total & 80 & 100 \\
\hline
\end{tabular}

Theft case was reported as a major problem faced by cashew farmers and shows $75 \%$ value on table 3.13. However, swelling was also reported as another major problem faced by cashew producers. Here, sorting has to be considered as great practice before, during and after the cashew drying.
Table 3.14: Shows if cashew nuts is soak before roasting

\begin{tabular}{|c|c|c|}
\hline Option & $\begin{array}{c}\text { No. of } \\
\text { respondent }\end{array}$ & Percentage (\%) \\
\hline Yes & 0 & 0 \\
\hline No & 80 & 100 \\
\hline Total & 80 & 100 \\
\hline
\end{tabular}

Apart from other cashew processing stages practiced by cashew farmers, soaking was not recognized as a major processing stage in cashew processing which is the initial processing stage for kernel production. Farmers preferred not to soak the cashew nuts and this indicates $100 \%$ on the table. Soaking should be the first cashew processing stage followed by roasting.

Table 3.15: Shows cashew nut is roasted

\begin{tabular}{|c|c|c|}
\hline Option & $\begin{array}{c}\text { No. of } \\
\text { respondent }\end{array}$ & Percentage (\%) \\
\hline Yes & 50 & 62.5 \\
\hline No & 30 & 37.5 \\
\hline Total & 80 & 100 \\
\hline
\end{tabular}

Roasting was considered an important processing stage with $62.5 \%$ respondents and has been practiced in the Port Loko District for quite some time now. However, some farmers did not consider it as an important stage in cashew processing with $37.5 \%$ respondents.

Table 3.16: Shows where cashew nuts is roasted

\begin{tabular}{|c|c|c|}
\hline Place & $\begin{array}{c}\text { No. of } \\
\text { respondent }\end{array}$ & Percentage (\%) \\
\hline Drum & 66 & 82.5 \\
\hline Pot & 6 & 7.5 \\
\hline Roaster & 2 & 2.5 \\
\hline Other & 6 & 7.5 \\
\hline Total & 80 & 100 \\
\hline
\end{tabular}

From the survey conducted, it shows that the main place for roasting cashew nuts wasthe drum with $82.5 \%$ respondents. Some cashew farmers also roasted their nuts in their pots, while others didit with roaster. 
Table 3.17: Shows problems faced with cashew nuts after roasting

\begin{tabular}{|c|c|c|}
\hline Problem & $\begin{array}{c}\text { No. of } \\
\text { respondent }\end{array}$ & Percentage (\%) \\
\hline Cracking & 50 & 62.5 \\
\hline Bad odor & 30 & 37.5 \\
\hline Total & 80 & 100 \\
\hline
\end{tabular}

Cracking wasshown to be a problem faced by cashew farmers although bad odour also reported to be another problem during roasting with $62.5 \%$ and $37.5 \%$ respectively on table 3.17 .

Table 3.18: Shows that the farmers deshelled their cashew nuts

\begin{tabular}{|c|c|c|}
\hline Option & $\begin{array}{c}\text { No. of } \\
\text { respondent }\end{array}$ & Percentage (\%) \\
\hline Yes & 50 & 62.5 \\
\hline No & 30 & 37.5 \\
\hline Total & 80 & 100 \\
\hline
\end{tabular}

Even though cracking has been a serious problem as a processing stage faced by cashew farmers, majority of the processors managed to deshell their cashew nuts for value addition with $62.5 \%$ agreed.

Table 3.19: Shows methods of deshelling cashew nut

\begin{tabular}{|c|c|c|}
\hline Method & $\begin{array}{c}\text { No. of } \\
\text { respondent }\end{array}$ & Percentage (\%) \\
\hline Mechanically & 16 & 20 \\
\hline Manually & 50 & 62.5 \\
\hline Other & 14 & 17.5 \\
\hline Total & 80 & 100 \\
\hline
\end{tabular}

Manual deshelling was the method used in the Kafubulum Chiefdom in the Port Loko District according to the interview conducted. However, some farmers also practiced mechanical method of deshelling. Also, there were other cashew farmers who practiced other methods of deshelling with $17.5 \%$ reported on the analysis.
Table 3.20: Shows problems faced in cashew nut deshelling

\begin{tabular}{|c|c|c|}
\hline Problem & $\begin{array}{c}\text { No. of } \\
\text { respondent }\end{array}$ & Percentage (\%) \\
\hline With stone & 50 & 62.5 \\
\hline With hand & 30 & 37.5 \\
\hline Other & 0 & 0 \\
\hline Total & 80 & 100 \\
\hline
\end{tabular}

The other methods of deshelling practiced by cashew farmers although reported to pose problem by the cashew farmers and such problems occurred with the use of stones with bear hands. Both of them showed significant values as indicated in table 3.20 above.

Table 3.21: Shows if kernel grading was done

\begin{tabular}{|c|c|c|}
\hline Option & $\begin{array}{c}\text { No. of } \\
\text { respondent }\end{array}$ & Percentage (\%) \\
\hline Yes & 50 & 62.5 \\
\hline No & 30 & 37.5 \\
\hline Total & 80 & 100 \\
\hline
\end{tabular}

Despite series of problems faced by the cashew producers, it was reported that the cashew producers went ahead in grading their cashew kernel with $62.5 \%$ agreed during the interview conducted.

Table 3.22: Shows methods of kernel grading

\begin{tabular}{|c|c|c|}
\hline Method & $\begin{array}{c}\text { No. of } \\
\text { respondent }\end{array}$ & Percentage (\%) \\
\hline Sorting by size & 50 & 62.5 \\
\hline Colour & 10 & 12.5 \\
\hline Weight & 4 & 5 \\
\hline Oil content & 4 & 5 \\
\hline Palatability & 4 & 5 \\
\hline Other & 4 & 10 \\
\hline Total & 80 & 100 \\
\hline
\end{tabular}

The aforementioned cashew kernel grading was done by sorting the sizes as indicated in table 3.22 with $62.5 \%$ value. Some farmers also graded their cashew kernels through colour observation, weight, oil content and palatability but all with minute percentages. 
Table 3.23: Shows the problems in kernel grading

\begin{tabular}{|c|c|c|}
\hline Problem & $\begin{array}{c}\text { No. of } \\
\text { respondent }\end{array}$ & Percentage (\%) \\
\hline Theft & 52 & 65 \\
\hline Price & 28 & 35 \\
\hline Total & 80 & 100 \\
\hline
\end{tabular}

After cashew kernel grading, the other problem faced by the producers was theft with $65 \%$ reported and also followed by the price of the cashew kernels which made the producers lose lots of income during the sales.

Table 3.24: Shows cashew kernel packaging

\begin{tabular}{|c|c|c|}
\hline Option & $\begin{array}{c}\text { No. of } \\
\text { respondent }\end{array}$ & Percentage (\%) \\
\hline Yes & 80 & 100 \\
\hline No & 0 & 0 \\
\hline Total & 80 & 100 \\
\hline
\end{tabular}

All Cashew farmers agreed to packaging their cashew kernel products as indicated in the above table.

Table 3.25: Shows the packaging materials of cashew kernels.

\begin{tabular}{|c|c|c|}
\hline Place & $\begin{array}{c}\text { No. of } \\
\text { respondent }\end{array}$ & Percentage (\%) \\
\hline Jute bag & 0 & 0 \\
\hline Plastic bag & 80 & 100 \\
\hline Carton & 0 & 0 \\
\hline Box & 0 & 0 \\
\hline Total & 80 & 100 \\
\hline
\end{tabular}

The only place for cashew kernel packaging was plastic bag with $100 \%$ responded from the survey conducted in Kafubulum Chiefdom, Port Loko District, Sierra Leone.

Table 3.26: Shows problems faced in kernel packaging

\begin{tabular}{|c|c|c|}
\hline Problem & $\begin{array}{c}\text { No. of } \\
\text { respondent }\end{array}$ & Percentage (\%) \\
\hline Yes & 80 & 100 \\
\hline No & 0 & 0 \\
\hline Total & 80 & 100 \\
\hline
\end{tabular}

It was reported that even though cashew kernel was packaged in plastic bags but the producers also faced serious challenges during this process. This was so as a result of acquisition of plastic bags.

Table 3.27: Shows if moisture content of the cashew kernel is normally determined

\begin{tabular}{|c|c|c|}
\hline Option & $\begin{array}{c}\text { No. of } \\
\text { respondent }\end{array}$ & Percentage (\%) \\
\hline Yes & 50 & 62.5 \\
\hline No & 30 & 37.5 \\
\hline Total & 80 & 100 \\
\hline
\end{tabular}

In cashew processing, the most paramount objective is the determination of the moisture content of the kernel, as $62.5 \%$ of the respondents interviewed agreed that they normally determine the moisture content of the cashew kernel. However, very few disagreed with $37.5 \%$ reported.

Table 3.28: Shows how moisture content of cashew kernel determined

\begin{tabular}{|c|c|c|}
\hline Instrument & $\begin{array}{c}\text { No. of } \\
\text { respondent }\end{array}$ & Percentage (\%) \\
\hline Moisture Metre & 30 & 37.5 \\
\hline By observation & 50 & 62.5 \\
\hline Total & 80 & 100 \\
\hline
\end{tabular}

No instrument was available during the determination of the moisture content of the cashew kernel except by observation with $62.5 \%$ reported. But however, very few cashew farmers have access to the Moisture Metre to determine the moisture content of dry cashew kernel as shown above.

Table 3.29: Shows the specific percentage moisture content of cashew kernel

\begin{tabular}{|c|c|c|}
\hline $\begin{array}{c}\text { Moisture content } \\
(\%)\end{array}$ & $\begin{array}{c}\text { No. of } \\
\text { respondent }\end{array}$ & Percentage (\%) \\
\hline 1 & 4 & 5 \\
\hline 2 & 6 & 7.5 \\
\hline 3 & 4 & 5 \\
\hline 4 & 6 & 7.5 \\
\hline 5 & 10 & 12.5 \\
\hline $6+$ & 80 & 62.5 \\
\hline Total & & 100 \\
\hline
\end{tabular}


The specific percentage moisture content of cashew kernel for most cashew farmers was reported as $6 \%$ and above and the corresponding percentage was $62.5 \%$ which is within the recommended moisture content of dry cashew kernel. However, some farmers normally dried their cashew kernel below the recommended moisture content of dry cashew kernel.

\subsection{Storage of cashew nut}

Table 3.31: Shows storage of cashew kernels

\begin{tabular}{|c|c|c|}
\hline Storage & $\begin{array}{c}\text { No. of } \\
\text { respondent }\end{array}$ & Percentage (\%) \\
\hline Jute bag & 0 & 0 \\
\hline Drum & 30 & 37.5 \\
\hline Plastic bag & 50 & 62.5 \\
\hline Total & 80 & 100 \\
\hline
\end{tabular}

It has been uncovered that two cashew kernel storage systems were practiced in the study area of this research. But never the less, plastic bag was the most practicable cashew kernel storage system with 50\% respondents agreed on table 3.31 above. However, cashew can be stored in jut bag and the final product (cashew kernel) can be stored in cartoon for export purposes.

Table 3.32: Shows the problems in the storage of cashew kernel

\begin{tabular}{|c|c|c|}
\hline Problem & $\begin{array}{c}\text { No. of } \\
\text { respondent }\end{array}$ & Percentage (\%) \\
\hline Germination & 56 & 70 \\
\hline Mould & 24 & 30 \\
\hline Total & 80 & 100 \\
\hline
\end{tabular}

Problem was encountered during the storage of cashew kernel when plastic bags were used and one of these problems was germination which had a70\% score. It has been indicated that the preferred storage system was not appropriate which also caused mould development as a result of Internal Moisture Migration (IMM) within the dried cashew kernels inside the plastic bags.

\subsection{Cashew Quality}

Table 3.33: Shows if cashew kernel is normally assessed and qualified

\begin{tabular}{|c|c|c|}
\hline Option & $\begin{array}{c}\text { No. of } \\
\text { respondent }\end{array}$ & Percentage (\%) \\
\hline Yes & 80 & 100 \\
\hline No & 0 & 0 \\
\hline Total & 80 & 100 \\
\hline
\end{tabular}

The quality of cashew kernels was assessed by the cashew producers as $100 \%$ respondents have been reported on the table above. The cashew farmers assess and qualify their cashew products before being taken to the market for sale.

Table 3.34: Shows how cashew kernel is normally assessed and qualified

\begin{tabular}{|c|c|c|}
\hline Quality & $\begin{array}{c}\text { No. of } \\
\text { respondent }\end{array}$ & Percentage (\%) \\
\hline Flavour & 0 & 0 \\
\hline Colour & 52 & 65 \\
\hline Taste & 28 & 35 \\
\hline Aroma & 0 & 0 \\
\hline Total & 80 & 100 \\
\hline
\end{tabular}

It can also be depicted from the table above that colour was used to assess and qualify the quality of cashew kernel by producers through the interview conducted. Some cashew farmers also use taste as another means of assessing and qualifying cashew kernel quality.

Table 3.35: Shows how cashew kernel is graded

\begin{tabular}{|c|c|c|}
\hline Grade & $\begin{array}{c}\text { No. of } \\
\text { respondent }\end{array}$ & Percentage (\%) \\
\hline Premium & 42 & 52.5 \\
\hline Grade 1 & 15 & 18.75 \\
\hline Grade 2 & 8 & 10.0 \\
\hline Grade 3 & 15 & 18.75 \\
\hline Total & 80 & 100 \\
\hline
\end{tabular}

Premium grade was the highest cashew quality reported on table 3.35 which shows $52.5 \%$ number of respondents. 
Grades 1 and 2 qualities were also reported on the data collected and analyzed.

Table 3.36: Shows the problems faced after kernel grading

\begin{tabular}{|c|c|c|}
\hline Problem & $\begin{array}{c}\text { No. of } \\
\text { respondent }\end{array}$ & Percentage (\%) \\
\hline Shortage & 60 & 75 \\
\hline Weight & 20 & 25 \\
\hline Total & 80 & 100 \\
\hline
\end{tabular}

It has also been depicted on table 3.36 that after premium, grade 1 and grade 2 obtained normally shortage and this was another serious threat or loss faced by the cashew producers. Also, weight loss was another problem discovered during the analyses and discussions of these data.

3.6 Cashew Marketing

Table 3.37: Shows sales in cashew kernel

\begin{tabular}{|c|c|c|}
\hline Option & $\begin{array}{c}\text { No. of } \\
\text { respondent }\end{array}$ & Percentage (\%) \\
\hline Yes & 80 & 100 \\
\hline No & 0 & 0 \\
\hline Total & 80 & 100 \\
\hline
\end{tabular}

From the table above, it shows that $100 \%$ of the farmers sold their cashew products to nearby contact partners and buying agents within the area.

Table 3.38: Shows where the kernel is sold

\begin{tabular}{|c|c|c|}
\hline Sales & $\begin{array}{c}\text { No. of } \\
\text { respondent }\end{array}$ & Percentage (\%) \\
\hline Contact partners & 40 & 50 \\
\hline Buying agents & 40 & 50 \\
\hline Local processors & 0 & 0 \\
\hline Total & 80 & 100 \\
\hline
\end{tabular}

According to the data above on table 3.38, it shows that, all cashew kernel products were sold to contact partners and buying agents within their vicinities.

\section{CONCLUSION}

\subsection{Summary}

After data analysis and discussions, the following summary were reached and provided sound based on the results obtained from the research.

Processing Facility

From the analyses and discussions of the results, it was summarized that the cashew farmers in the Kafubulum Chiefdom of Port Loko, North of Sierra Leone have no processing facility to produce cashew kernel except for roasting and drying the cashew nuts.This was shown from the analyses that $100 \%$ of these producers were willing to process their cashew products. There is therefore the need to avail processing facilities to cashew farmers so that they can add value to their produce and by extension earn additional income.

Quality Assessment

Never the less, the cashew farmers did assess their cashew kernel based on colour and taste. Grades like Premium, Grade 1, Grade 2 and Grade 3 were obtained from the assessment made. For quality management, Premium is the accepted cashew kernel grade. In general, the quality of the cashew kernel was high as farmers were able to maintain the exact required kernel moisture content from the analyses made.

\section{Cashew Yield}

The Red and Yellow Colour cashew gave better yield in the Kafubulum Chiefdom from the interview conducted. Upon the two colours, Red Colour reported to be high yielding with $55 \%$ respondents.

It can be concluded by [12] from the literature that over 30 cashew varieties were planted in India whereas for Kafubulum Chiefdom, 2 cashew varieties were discovered. Generally, the mode of production, collection and storage practices affect the quality of cashew nuts. Smallholder farmers may harvest apple to meet urgent cash needs, without minding the maturity status of the nuts. From the literature review, all post-harvest operations relating to cashew kernel production were practiced, but from the survey conducted, most practices were skipped. This practice contributes to about $40 \%$ post-harvest losses of cashew nuts from the literature while for this research no post-harvest losses were discovered in the study area.

Cashew nut processing is generally done on a home scale and factory scale. In the home scale, the dried nuts are burnt 
in an open fire and hand shelled, from the research conducted, small scale kernel production was discovered.

Cashew tree yield of 1.5 to $4 \mathrm{~kg}$ of nuts/tree have been reported for Africa [1], and 7 to $11 \mathrm{~kg}$ of nut/tree for South Asia [1]. In Nigeria, mature cashew tree nut yields of $<1 \mathrm{~kg}$ to over $20 \mathrm{~kg}$ of nuts were obtained [5]. Nut yield in the range of 7.8 to $14.0 \mathrm{~kg} /$ tree were also observed in some Nigerian cashew germplasm collections [6]. [8] obtained nut yields of $0.25,2.41,8.65,10.02$ and $30.50 \mathrm{~kg} /$ tree for some Tanzanian varieties. In India, cashew varieties with tree yield capacity of 10 to $13 \mathrm{~kg}$ of nuts/tree have been distributed to farmers [13], but for this research focus was made on the production, processing and quality management but little on cashew yield.

\section{ACKNOWLEDGEMENTS}

I am most grateful to the Almighty God for the grace and strength he provided each day to make this publication with success. My utmost appreciation goes to my colleague staff of Kenema Forestry and Tree Crops Research Centre (KFTCRC) especially Paul Musa Lahai and Mustapha Sly Bayon who have contributed immensely for the success of this publication.

My appreciation also goes to my lovely wife Vivian Aminata Sesay and sons, Momoh Fovian Turay and Frederick G. M Lamin and wonderful Turay Family and others in Magbeni, Koya Chiefdom, Port Loko District and the people of Mayekson for the emotional support.

\section{REFERENCES}

[1] African Cashew Alliance. "Competitiveness of the African Cashew Sector, African Cashew Initiative (ACi)." February, 2011.

[2] Aliyu, O.M. and J.A. Awopetu, 2007. Assessment of genetic diversity in three populations of cashew using protein-isozyme electrophoresis analysis. Genetic Resource. Crop Evol,54: 1489-1497.

[3] Aliyu OM, 2000. Development of effective vegetative propagation technique (budding) in cashew. Annual Research Report of the Cocoa Research Institute of Nigeria, Ibadan, Nigeria. Pp. 35-35.

[4] Aliyu OM, 2001. Development of rapid method of propagating improved cultivars of cashew through budding, grafting and marcotting. Annual Research Report of the Cocoa Research Institute of Nigeria, Ibadan, Nigeria. Pp. 30-31

[5] Aliyu OM, 2004 Characteristics and compatibility studies in Cashew (Anacardium occidentale L.). Ph.D. Thesis, University of Ilorin, Nigeria. $266 \mathrm{pp}$.
[6] Aliyu OM, Awopetu JA (2007a). Multivariate Analysis of Cashew (Anacardium occidentale L.) Germplasm in Nigeria. Silvae Genetica 56: 3-4.

[7] Chemonics International Inc, 2002, Subsector Assessment of the Nigerian Cashew Industry. Available at http://pdf.usaid.gov/pdf docs/PNACY675.pdf. (Accessed April18, 2008) Clarke, Susan E; Gary L. Davis (1992), Post federal Local Economic Development strategies; Economic Development Quarterly 6 (2): 187-198. Available at http://en.wikipedia.org/wiki/Waves of Economic Development. (Accessed, January10, 2011).

[8] Desai AR, 2008. Molecular diversity and phenotyping of selected cashew genotypes of Goa, and physiological response of cv. Goa-1 to in situ moisture conservation. Thesis submitted to the University of Agricultural Sciences, Dharwad in partial fulfilment of the requirements for the Degree of Doctor of Philosophy in Horticulture. Department of Horticulture, College of Agriculture, Dharwad University of Agricultural Sciences, Dharwad-580 005.

[9] IRD, 2001. Cashew seed selection, Planting, and Production techniques. International Relief and Development Publication. The Gambia. Pp. 14-19.

[10] Martin PJ, Kasuga LJ 1995. Variation in cashew tree yield in South-East Tanzania and the implication for management of cashew smallholder farmers in Tanzania. Exp. Agric. 72:261268.

[11] Sagar, 2007. Propagation studies in cashew nut (Anacardium occidentale L.) under mist house conditions. An M.SC. Thesis submitted to the Department of Horticulture College of Agriculture, Dharwad University of Agricultural Sciences, Dharwad-580 005.

[12] Sharma VK, 2004. Trees and Protection of Environment. Deep and Deep Publications, 63.

[13] The Hindu, 2000. Online edition of India's National Newspaper Thursday, December 14 2000. Source: http://hindu.com/2000/12/14/stories/0814002a.htm 